\title{
Article \\ Engineered Nanoparticles with Decoupled Photocatalysis and Wettability for Membrane-Based Desalination and Separation of Oil-Saline Water Mixtures
}

\author{
Bishwash Shrestha ${ }^{+}\left(\mathbb{D}\right.$, Mohammadamin Ezazi ${ }^{+}\left(\mathbb{D}\right.$ and Gibum Kwon * ${ }^{*}$ \\ Department of Mechanical Engineering, University of Kansas, Lawrence, KS 66045, USA; \\ bishwashs@ku.edu (B.S.); aminezazi@ku.edu (M.E.) \\ * Correspondence: gbkwon@ku.edu \\ + Equal contributions.
}

Citation: Shrestha, B.; Ezazi, M.; Kwon, G. Engineered Nanoparticles with Decoupled Photocatalysis and Wettability for Membrane-Based Desalination and Separation of Oil-Saline Water Mixtures. Nanomaterials 2021, 11, 1397. https:// doi.org/10.3390/nano11061397

Academic Editor: Gheorghe Nechifor

Received: 8 May 2021

Accepted: 22 May 2021

Published: 25 May 2021

Publisher's Note: MDPI stays neutral with regard to jurisdictional claims in published maps and institutional affiliations.

\begin{abstract}
Membrane-based separation technologies are the cornerstone of remediating unconventional water sources, including brackish and industrial or municipal wastewater, as they are relatively energy-efficient and versatile. However, membrane fouling by dissolved and suspended substances in the feed stream remains a primary challenge that currently prevents these membranes from being used in real practices. Thus, we directly address this challenge by applying a superhydrophilic and oleophobic coating to a commercial membrane surface which can be utilized to separate and desalinate an oil and saline water mixture, in addition to photocatalytically degrading the organic substances. We fabricated the photocatalytic membrane by coating a commercial membrane with an ultraviolet (UV) light-curable adhesive. Then, we sprayed it with a mixture of photocatalytic nitrogen-doped titania $\left(\mathrm{N}-\mathrm{TiO}_{2}\right)$ and perfluoro silane-grafted silica $\left(\mathrm{F}_{-} \mathrm{SiO}_{2}\right)$ nanoparticles. The membrane was placed under a UV light, which resulted in a chemically heterogeneous surface with intercalating high and low surface energy regions (i.e., $\mathrm{N}-\mathrm{TiO}_{2}$ and $\mathrm{F}-\mathrm{SiO}_{2}$, respectively) that were securely bound to the commercial membrane surface. We demonstrated that the coated membrane could be utilized for continuous separation and desalination of an oil-saline water mixture and for simultaneous photocatalytic degradation of the organic substances adsorbed on the membrane surface upon visible light irradiation.
\end{abstract}

Keywords: photocatalytic nanoparticles; wettability; perfluorinated silica nanoparticles; oil-water separation; membrane fouling

\section{Introduction}

Modulating the surface wettability plays a vital role in a solid-liquid system and has found increasing interest in practical applications, including self-cleaning [1,2], microfluidics $[3,4]$, and liquid separation $[5,6]$. Based on the contact angle $(\theta)$ for high (e.g., water) and low surface tension liquids (e.g., oil), a surface can be grouped into four wettability classifications: omniphobic $\left(\theta_{\text {water }}>90^{\circ}\right.$ and $\left.\theta_{\text {oil }}>90^{\circ}\right)$, hydrophobic and oleophilic $\left(\theta_{\text {water }}>90^{\circ}\right.$ and $\left.\theta_{\text {oil }}<90^{\circ}\right)$, hydrophilic and oleophobic $\left(\theta_{\text {water }}<90^{\circ}\right.$ and $\left.\theta_{\text {oil }}>90^{\circ}\right)$, and omniphilic $\left(\theta_{\text {water }}<90^{\circ}\right.$ and $\left.\theta_{\text {oil }}<90^{\circ}\right)$ [7,8]. We [9-11] and others [12-14] have demonstrated that a low surface energy coating, in conjunction with the surface texture, can result in a non-wetting Cassie-Baxter state with air trapped between the contacting liquid and the solid surface.

Organofluorine is perhaps the most prevalent material for lowering the overall surface free energy and rendering the surface repellent to liquids [10]. It has been extensively employed to fabricate not only a surface with omniphobic $[15,16]$ or superomniphobic wettability (i.e., $\theta^{*}{ }_{\text {water }}>150^{\circ}$ and $\theta^{*}{ }_{\text {oil }}>150^{\circ}$ ) $[9,17,18]$ but also those with selective (i.e., hydrophobic and oleophilic or hydrophilic and oleophobic) wettability [19-22]. For example, Mertens et al. [19] utilized a combination of photolithography and oxygen plasma 
treatment to fabricate a nanocrystalline diamond surface with hydrophobic and hydrophilic arrays. Howarter et al. [20] grafted a perfluorinated polyethylene glycol on a silicon surface which could exhibit hydrophilic and oleophobic wettability.

The utility of surfaces with selective wettability can be further extended by incorporating them with photocatalytic nanoparticles that can degrade organic substances upon light irradiation [23-25]. Such a photocatalytic surface with selective wettability has demonstrated the potential for a wide range of practical applications, including anti-fouling [26,27], self-cleaning [28,29], and bactericidal coating [30]. Recent studies [31-34] have revealed that membranes with selective wettability can further benefit by incorporating photocatalytic nanoparticles that can radically transform physical filtration into chemically reactive processes. Thus, it can progressively eliminate the inherent shortcomings of conventional membrane-based filtration, such as pollutant degradation and membrane fouling [23]. Zhao et al. [35] reported on a polyacrylonitrile membrane coated with a fluorinated agent and photocatalytic $\mathrm{ZnO}$. The membrane exhibited remediation of wastewater upon ultraviolet (UV) light irradiation and resistance to fouling. Luster et al. [36] fabricated an $\mathrm{N}$-doped, $\mathrm{TiO}_{2}$-coated alumina membrane and demonstrated the photocatalytic degradation of carbamazepine (CBZ) as a model pollutant under simulated solar irradiation. Further, Coelho et al. [26] coated a filter paper with zirconia-doped cerium to prepare a photocatalytic membrane. The membrane demonstrated flux recovery by photocatalytic degradation of humic acid as a foulant.

Before these photocatalytic membranes with desired wettability can be utilized for practical applications, they need to fulfill the following three conditions [37,38]. First, the membrane's wettability must remain unchanged by a photocatalytic reaction. Similarly, its physical and chemical integrity must not be affected by a photocatalytic reaction, particularly if the membrane is organic. Lastly, the coating (e.g., photocatalytic nanoparticles) needs to remain undetached when a high hydraulic shear force is exerted.

In this work, we engineered a visible light-responsive photocatalytic coating with superhydrophilic and oleophobic wettability both in air and underwater by utilizing nitrogen-doped titania $\left(\mathrm{N}-\mathrm{TiO}_{2}\right)$ and perfluoro silane-grafted silica $\left(\mathrm{F}-\mathrm{SiO}_{2}\right)$ nanoparticles. The coating was sprayed onto a commercial membrane surface with a UV-curable adhesive. Subsequent irradiation of UV light resulted in a chemically heterogeneous surface with intercalating high surface energy $\left(\mathrm{N}-\mathrm{TiO}_{2}\right)$ and low surface energy $\left(\mathrm{F}-\mathrm{SiO}_{2}\right)$ regions that were securely bound to the surface. Both the wettability and the integrity of the membrane remained unaffected throughout the photocatalytic degradation process of the organic substances when exposed to visible light irradiation. This can be attributed to the robust chemistry of the cured adhesive that protected the perfluoro silane molecules grafted to the $\mathrm{SiO}_{2}$ nanoparticles, as well as the underlying membrane from the reactive radical species generated when it was exposed to visible light irradiation. Thus, the coated membrane can be utilized for continuous separation and desalination of an oil-saline water mixture and simultaneous photocatalytic degradation of the organic substances adsorbed on the membrane surface upon visible light irradiation.

\section{Materials and Methods}

\subsection{Chemicals}

Titanium butoxide (TBOT), tetraethyl orthosilicate (TEOS), triethylamine (TEA), sodium dodecyl sulfate (SDS), and sodium chloride $(\mathrm{NaCl})$ were purchased from Millipore Sigma, St. Louis, MO, USA. The $1 \mathrm{H}, 1 \mathrm{H}, 2 \mathrm{H}, 2 \mathrm{H}$-perfluorodecyl trichlorosilane (perfluoro silane) was purchased from Alfa Aesar, Lancashire, UK. Ethanol, acetone, isopropyl alcohol, hydrochloric acid $(\mathrm{HCl})$, nitric acid $\left(\mathrm{HNO}_{3}\right)$, and n-hexadecane were purchased from Fisher Chemical, Fairlawn, NJ, USA. The Norland ultraviolet (UV) light-curable optical adhesive (NOA 61) was purchased from Norland Products Inc, Cranbury, NJ, USA. The commercial TRISEP ACM5 membrane was purchased from Sterlitech, Kent, WA, USA. 


\subsection{Synthesis of $\mathrm{N}-\mathrm{TiO}_{2}$ Nanoparticles}

Titanium butoxide (TBOT, $5.0 \mathrm{~g}$ ) was added dropwise to isopropyl alcohol $(79 \mathrm{~g})$, followed by the addition of deionized (DI) water $(910 \mathrm{~g})$. Nitric acid $\left(\mathrm{HNO}_{3}, 0.01 \mathrm{M}\right)$ was added to the solution to adjust the $\mathrm{pH}$ to 2 . Subsequently, triethylamine was added dropwise to the solution. Please note that the molar ratios of TEA to TBOT were 0.5, 1.0, 2.0, and 3.0. The solution was stirred for $12 \mathrm{~h}$ at $30^{\circ} \mathrm{C}$. The precipitates were collected by centrifugation and thoroughly rinsed by DI water and ethanol. Upon vacuum drying for $10 \mathrm{~h}$, the deep-yellow, nitrogen-doped titanium dioxide $\left(\mathrm{N}-\mathrm{TiO}_{2}\right)$ nanoparticles were obtained.

\subsection{Synthesis of $\mathrm{F}-\mathrm{SiO}_{2}$ Nanoparticles}

Tetraethyl orthosilicate (TEOS, $1.0 \mathrm{~g}$ ) was added dropwise to a solution of hydrochloric acid $(\mathrm{HCl}, 0.01 \mathrm{M})$ in DI water $(100 \mathrm{~g})$, followed by the addition of $1 \mathrm{H}, 1 \mathrm{H}, 2 \mathrm{H}, 2 \mathrm{H}-$ perfluorodecyl trichlorosilane $(1.0 \mathrm{~g})$. The solution was stirred for $60 \mathrm{~min}$ at $60^{\circ} \mathrm{C}$, and the precipitates were collected by centrifugation. Following a thorough rinsing by DI water and ethanol, and after $10 \mathrm{~h}$ of vacuum drying, the perfluoro silane-grafted silica $\left(\mathrm{F}-\mathrm{SiO}_{2}\right)$ nanoparticles were obtained.

\subsection{Photocatalytic Membrane Fabrication}

A commercial membrane surface was spin-coated with a Norland ultraviolet (UV) light-curable optical adhesive (NOA 61) (1.0 wt\% in acetone). Please note that the commercial membrane (i.e., Sterlitech TRISEP ACM5) consisted of three layers of a thin polyamide layer with a molecular weight cut-off equal to $100 \mathrm{Da}$, a porous polysulfone layer, and a non-woven polyester as the support. The suspension of the $\mathrm{N}-\mathrm{TiO}_{2}$ and $\mathrm{F}_{-}-\mathrm{SiO}_{2}$ nanoparticles mixture (i.e., $\mathrm{N}-\mathrm{TiO}_{2} / \mathrm{F}-\mathrm{SiO}_{2}$ ) in $\mathrm{DI}$ water $(10 \mathrm{wt} \%$ ) was then sprayed (iWata spray gun, Anest iwata, Yokohama, Japan) onto the adhesive-coated membrane for one minute. The spraying distance and nitrogen gas pressure were maintained at $15 \mathrm{~cm}$ and $200 \mathrm{kPa}$, respectively. Please note that the concentrations of $\mathrm{N}-\mathrm{TiO}_{2}$ nanoparticles in the $\mathrm{N}-\mathrm{TiO}_{2} / \mathrm{F}-$ $\mathrm{SiO}_{2}$ mixture were $0 \mathrm{wt} \%, 20 \mathrm{wt} \%, 40 \mathrm{wt} \%, 60 \mathrm{wt} \%, 80 \mathrm{wt} \%$, and $100 \mathrm{wt} \%$. Subsequently, the membrane surface was irradiated by a long-wavelength UV light $(100 \mathrm{~W}, \lambda=365 \mathrm{~nm}$, Analytikjena, Upland, CA, USA) for $5 \mathrm{~min}$ to cure the adhesive. The membrane was thoroughly rinsed with DI water and ethanol.

\subsection{Preparation of the Oil-in-Water Emulsion Dissolved with Salt}

An oil-in-water emulsion containing salt was prepared by vigorous mixing of $n$ hexadecane and DI water (10:90 vol:vol n-hexadecane:water) dissolved with salt $(\mathrm{NaCl}$, $1.0 \mathrm{wt} \%$ with respect to the water mass). Sodium dodecyl sulfate (SDS, $0.015 \mathrm{wt} \%$ ) was added to stabilize the emulsion.

\section{6. $\mathrm{N}-\mathrm{TiO}_{2}$ and $\mathrm{F}-\mathrm{SiO}_{2}$ Size Measurements}

The average size of the $\mathrm{N}-\mathrm{TiO}_{2}$ and $\mathrm{F}-\mathrm{SiO}_{2}$ nanoparticles was measured by utilizing dynamic light scattering (DLS) (ZetaPALS zeta potential analyzer, Brookhaven Instruments, Holtsville, NY, USA) equipped with a BI-9000AT digital autocorrelator. Suspensions of $\mathrm{N}-\mathrm{TiO}_{2}(0.01 \mathrm{wt} \%)$ and $\mathrm{F}-\mathrm{SiO}_{2}(0.01 \mathrm{wt} \%)$ were prepared in DI water, followed by ultrasonication.

\section{7. $\mathrm{N}-\mathrm{TiO}_{2}$ Crystal Structure Analyses}

The crystal structure of $\mathrm{N}-\mathrm{TiO}_{2}$ was studied by powder X-ray diffraction (XRD) (PANalytical Model X'Pert PRO diffractometer, PANalytical, Almelo, The Netherlands) with $\mathrm{Cu}$ $\mathrm{K} \alpha$ radiation $(\lambda=1.54 \AA)$ by scanning at a rate of $2^{\circ}(2 \theta) \mathrm{min}^{-1}$. X-ray photoelectron spectroscopy (XPS) was utilized to study the nitrogen doping of $\mathrm{N}-\mathrm{TiO}_{2}$. XPS was conducted by a Phi Versaprobe II, Ulvac-PHI, Kanagawa, Japan utilizing monochromatic source Mg Ka. 


\section{8. $\mathrm{N}-\mathrm{TiO}_{2}$ and $\mathrm{F}-\mathrm{SiO}_{2}$ Absorbance Measurements}

Ultraviolet-visible (UV-Vis) spectrophotometry was utilized to analyze the nanoparticles' absorbance spectrum. UV-Vis spectrophotometry was conducted by utilizing a Thermo Evolution 600, Waltham, MA, USA at a scan rate of $240 \mathrm{~nm} \mathrm{~min}{ }^{-1}$ and a data interval of $2 \mathrm{~nm}$.

\section{9. $\mathrm{N}-\mathrm{TiO}_{2}$ Photocatalytic Performance Measurements}

The photocatalysis performance of $\mathrm{N}-\mathrm{TiO}_{2}$ nanoparticles was analyzed by conducting the dye degradation test. UV-Vis spectrophotometry was utilized to study the dye degradation performance. $\mathrm{N}-\mathrm{TiO}_{2}$ nanoparticles $(0.5 \mathrm{wt} \%)$ were dispersed in $\mathrm{DI}$ water dissolved with Solvent Blue 38 dye $(0.5 \mathrm{wt} \%)$. Of the dispersion, $20 \mathrm{~mL}$ was poured into a glass beaker equipped with a magnetic stirrer. The visible light $(13.1 \mathrm{~W}$, Sugarcube ultraLED, USHIO, Vergennes, VT, USA) guide was submerged into the beaker to irradiate the dispersion. A small quantity $(2 \mathrm{~mL})$ of the dispersion was taken every $1 \mathrm{~h}$. It was centrifuged and filtered by filter paper, followed by UV-Vis spectrophotometry. UV-Vis spectrophotometry was conducted at a scan rate of $240 \mathrm{~nm} \mathrm{~min}{ }^{-1}$ and a data interval of $2 \mathrm{~nm}$.

\subsection{Membrane Surface Analysis}

Scanning electron microscopy (SEM, FEI Versa 3D DualBeam, Hillsboro, OR, USA) was utilized to study the surface porosity and texture of the $\mathrm{N}-\mathrm{TiO}_{2} / \mathrm{F}-\mathrm{SiO}_{2}$ coated membrane. An accelerating voltage of $10 \mathrm{kV}$ was utilized. All surfaces were sputter-coated with a gold layer $(\approx 4-5 \mathrm{~nm})$ to prevent the charging effect.

\subsection{Visible Light Intensity Measurement}

A photometer (Fisherbrand Traceable DualDisplay Lightmeter, Control company, Webster, TX, USA) was utilized to measure the intensity of the incident visible light on the membrane surface. The photometer was placed underneath the top cover of the cross-flow cell and irradiated by the visible light source from the same distance $(\approx 5 \mathrm{~cm})$ at which the membrane was irradiated during the separation and desalination.

\subsection{Salt and Oil Concentration Measurements}

We determined the salt concentration in the water-rich permeate by calculating the electrical conductivity of the permeate and comparing the value with the calibration curve. Two probes ( $1 \mathrm{~cm}^{2}$ each) of a multimeter (GDT-3190, Gardner Bender, New Berlin, WI, USA) at a distance of $2 \mathrm{~cm}$ were submerged in the permeate $(20 \mathrm{~mL})$. The multimeter measured the electrical resistance $(R)$, which was converted to electrical resistivity. Subsequently, the inverse of the electrical resistivity yielded the electrical conductivity (s). We determined the oil concentration by utilizing thermogravimetric analyses (TGA, PerkinElmer PYRIS 1, PerkinElmer, Waltham, MA, USA). Approximately $10 \mathrm{mg}$ of the water-rich permeate was heated from room temperature $\left(\approx 22^{\circ} \mathrm{C}\right)$ to $110^{\circ} \mathrm{C}$ at a rate of $5^{\circ} \mathrm{C} \mathrm{min}-1$, followed by maintaining the temperature at $110^{\circ} \mathrm{C}$ for $50 \mathrm{~min}$.

\subsection{Engineering a Continuous Separation and Desalination Apparatus}

We engineered a continuous separation and desalination apparatus consisting of a cross-flow cell (CF042A, Sterlitech, Kent, WA, USA), a feed storage tank, a pump (2SF22SEEL, WEG industries, Jaraguá do Sul, Brazil), a differential pressure gauge (DPG409500DWU, OMEGA, Stamford, CT, USA), a visible light source, and a permeate tank. The membrane with an effective surface area of $\approx 42 \mathrm{~cm}^{2}$ was sandwiched in between two transparent acrylic counterparts of the cross-flow cell. The membrane surface was irradiated by visible light of varying intensities. 


\section{Results and Discussion}

\subsection{Synthesis of $\mathrm{N}-\mathrm{TiO}_{2}$ and Characterization of Its Photocatalysis upon Visible Light Irradiation}

To fabricate a visible-light-responsive photocatalytic coating with selective wettability (i.e., hydrophilic and oleophobic), we utilized a mixture of nitrogen-doped titanium dioxide $\left(\mathrm{N}-\mathrm{TiO}_{2}\right)$ and perfluoro silane-grafted silica $\left(\mathrm{F}-\mathrm{SiO}_{2}\right)$ nanoparticles. $\mathrm{N}-\mathrm{TiO}_{2}$ can degrade organic substances when it is exposed to visible light irradiation [39] and exhibit hydrophilic wettability [40], while $\mathrm{F}_{-} \mathrm{SiO}_{2}$ can lower the overall surface free energy $\left(\gamma_{\mathrm{sv}}\right)$ [41]. We hypothesized that an optimal balance of $\mathrm{N}-\mathrm{TiO}_{2}$ and $\mathrm{F}-\mathrm{SiO}_{2}$ could result in hydrophilic and oleophobic wettability.

To verify this hypothesis, we first synthesized the $\mathrm{N}-\mathrm{TiO}_{2}$ nanoparticles by utilizing the sol-gel method [42] (further described in the Section 2). Triethylamine (TEA) and titanium butoxide (TBOT) were used as a nitrogen dopant and a $\mathrm{TiO}_{2}$ precursor, respectively (Figure 1a). Hydrolysis of the TBOT (concentration $=0.5 \mathrm{wt} \%$ ) in an acidic solution $(\mathrm{pH} \approx 2.0)$ that was dissolved with TEA (concentration $=0.3 \mathrm{wt} \%$ ) resulted in $\mathrm{N}-\mathrm{TiO}_{2}$ nanoparticles with an average diameter of $50 \mathrm{~nm} \pm 1 \mathrm{~nm}$ (Supporting Information, Section S1). During this reaction, the TEA introduced nitrogen (e.g., elemental nitrogen or complex nitrogen species such as $\mathrm{NO}, \mathrm{NO}_{2}$, or $\mathrm{NH}$ ) into the $\mathrm{TiO}_{2}$ lattice [43]. X-ray photoelectron spectroscopy (XPS) spectra demonstrated a peak at a binding energy of $\approx 399.2 \mathrm{eV}$, which indicated the presence of anionic nitrogen from the O-Ti-N bond [42], while the neat $\mathrm{TiO}_{2}$ lacked such a peak (Figure 1b).

Doping with nitrogen can narrow the bandgap energy of the $\mathrm{TiO}_{2}$, which may extend the absorption spectra further toward the visible light region (i.e., $390 \mathrm{~nm}<\lambda<750 \mathrm{~nm}$ ) [44]. The ultraviolet-visible (UV-Vis) spectrophotometry data verified that $\mathrm{N}-\mathrm{TiO}_{2}$ absorbed a broad range of the visible light spectrum, whereas the neat $\mathrm{TiO}_{2}$ and $\mathrm{SiO}_{2}$ showed negligible absorption (Figure 1c). Furthermore, the results showed that the $\mathrm{N}^{-\mathrm{TiO}_{2}}$ fabricated with a higher molar ratio of TEA to TBOT (i.e., higher dopant concentration) tended to exhibit stronger absorbance in the range of wavelengths from $390 \mathrm{~nm}$ to $750 \mathrm{~nm}$. However, once the molar ratio exceeded 2.0, this would have a negligible effect on the absorbance of the resulting $\mathrm{N}-\mathrm{TiO}_{2}$. Thus, we utilized a TEA-to-TBOT molar ratio of 2.0 (hereafter denoted as $\mathrm{N}-\mathrm{TiO}_{2}$ ) in this study.

Given that the resulting $\mathrm{N}-\mathrm{TiO}_{2}$ exhibited a photocatalytic anatase crystalline phase (Supporting Information, Section S2), we demonstrated that it could degrade organic substances upon visible light irradiation. Figure $1 \mathrm{~d}$ presents the time-dependent degeneration of the absorbance for water dissolved with organic dye (Solvent Blue 38, concentration $=0.5 \mathrm{wt} \%$ ) and $\mathrm{N}-\mathrm{TiO}_{2}$ (concentration $=0.5 \mathrm{wt} \%$ ). The light intensity $(I)$ was maintained at $I \approx 198 \mathrm{~mW} \mathrm{~cm}^{-2}$ (see Section 2). The water solution became nearly colorless after $10 \mathrm{~h}$ of irradiation, indicating that almost all of the dye molecules were degraded. Please note that the dye molecules degraded more rapidly when placed under a higher intensity of light (Supporting Information, Section S3).

The $\mathrm{F}_{-} \mathrm{SiO}_{2}$ nanoparticles were synthesized through the hydrolysis of tetraethyl orthosilicate (TEOS), followed by grafting of $1 \mathrm{H}, 1 \mathrm{H}, 2 \mathrm{H}, 2 \mathrm{H}$-perfluorodecyl trichlorosilane [41,45] (see Section 2). The average diameter of the $\mathrm{F}_{-} \mathrm{SiO}_{2}$ nanoparticles was $50 \mathrm{~nm} \pm 2 \mathrm{~nm}$ (Supporting Information, Section S4). 

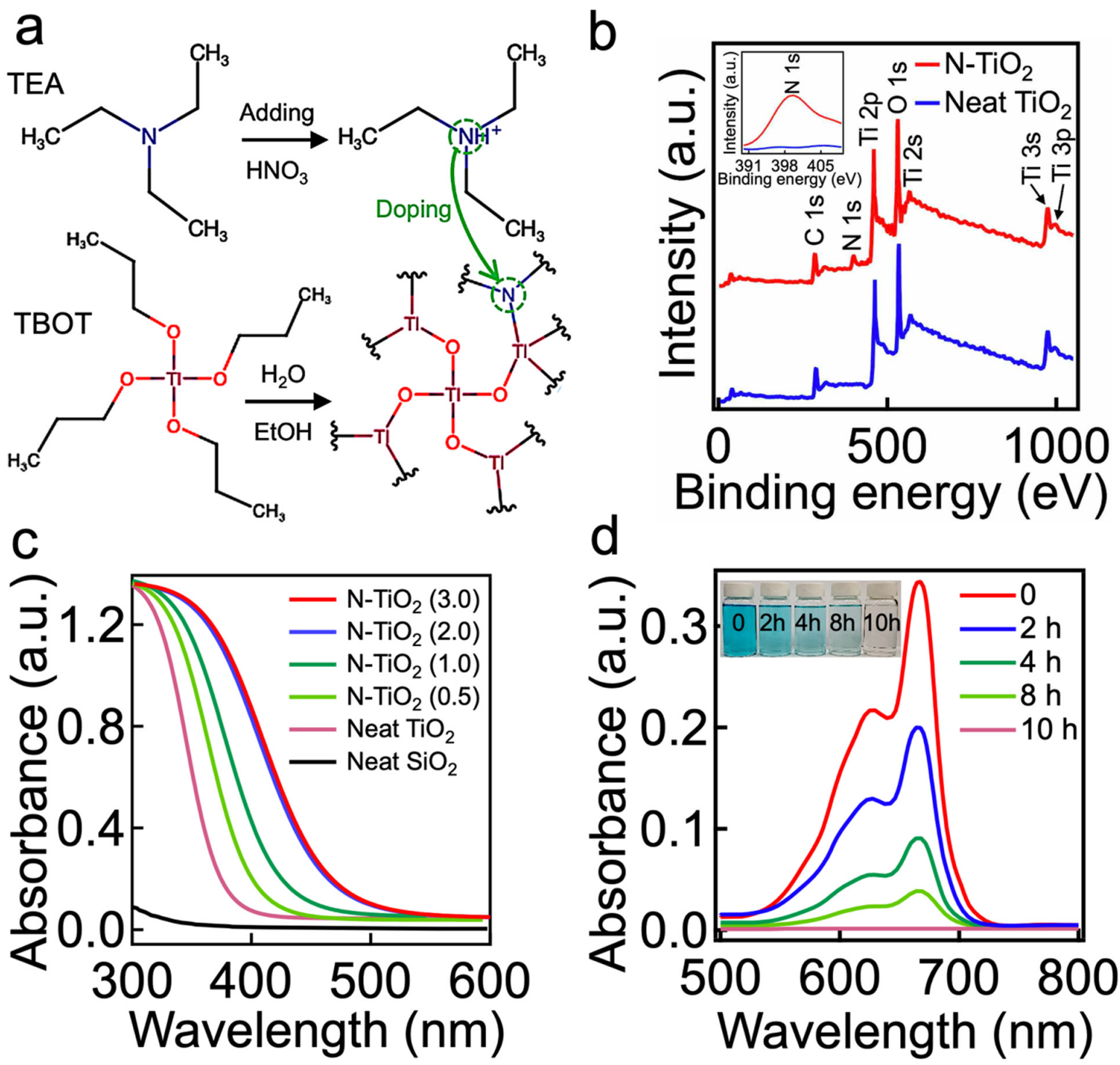

Figure 1. (a) Schematic illustrating the synthesis of $\mathrm{N}-\mathrm{TiO}_{2}$ nanoparticles by utilizing titanium butoxide (TBOT) and triethylamine (TEA) as a $\mathrm{TiO}_{2}$ precursor and nitrogen dopant, respectively. (b) The XPS spectrum of $\mathrm{N}-\mathrm{TiO}_{2}$, exhibiting characteristic peaks of $\mathrm{N} \mathrm{1s,} \mathrm{Ti} \mathrm{2p,} \mathrm{and} \mathrm{O} \mathrm{1s.} \mathrm{The} \mathrm{spectrum} \mathrm{of} \mathrm{a} \mathrm{neat} \mathrm{TiO}_{2}$ is also shown for comparison. The inset shows the core level spectrum of characteristic $\mathrm{N}$ 1s. (c) Ultraviolet-visible (UV-Vis) absorption spectra of $\mathrm{N}_{-} \mathrm{TiO}_{2}$ synthesized by varied molar ratios of TEA to TBOT (e.g., 0.5, 1.0, 2.0, and 3.0). Neat $\mathrm{TiO}_{2}$ and $\mathrm{SiO}_{2}$ absorption spectra are also shown for comparison. (d) UV-Vis absorption spectra of water dissolved with $\mathrm{N}_{-} \mathrm{TiO}_{2}$ and Solvent Blue dye as a function of the visible light irradiation time. The inset is a photograph showing the water dissolved with Solvent Blue dye after visible light irradiation for $2 \mathrm{~h}, 4 \mathrm{~h}, 8 \mathrm{~h}$, and $10 \mathrm{~h}$. The as-prepared water dissolved with Solvent Blue dye (concentration $=0.5 \mathrm{wt} \%$ ) is also shown.

\subsection{Fabrication and Characterization of $\mathrm{N}-\mathrm{TiO}_{2} / \mathrm{F}-\mathrm{SiO}_{2}$ Coated Membrane}

By utilizing $\mathrm{N}-\mathrm{TiO}_{2}$ and $\mathrm{F}-\mathrm{SiO}_{2}$ nanoparticles, we created a photocatalytic membrane with hydrophilic and oleophobic wettability both in air and saline water. A commercial filter (TRISEP ACM5) was utilized as a membrane, on which our visible light-responsive photocatalytic coating with selective wettability was applied. Please note that the TRISEP ACM5 was chosen because of its applicability to a wide range of separation processes [46]. First, we spin-coated the membrane surface with a thiol-ene-based UV-curable adhesive. Immediately following this step, a solution of $\mathrm{N}-\mathrm{TiO}_{2}$ and $\mathrm{F}-\mathrm{SiO}_{2}$ (i.e., $\mathrm{N}-\mathrm{TiO}_{2} / \mathrm{F}_{-} \mathrm{SiO}_{2}$ ) (concentration $=10 \mathrm{wt} \%$, Section 2 ) was sprayed for one minute. Then, the membrane was irradiated by UV light $\left(\lambda=365 \mathrm{~nm}\right.$, intensity $\left.\approx 78 \mathrm{~mW} \mathrm{~cm}^{-2}\right)$ for five minutes at room 
temperature $\left(\approx 22{ }^{\circ} \mathrm{C}\right)$ to cure the adhesive. Please note that we varied the concentrations of $\mathrm{N}-\mathrm{TiO}_{2} / \mathrm{F}_{-} \mathrm{SiO}_{2}$ (e.g., 0, $20 \mathrm{wt} \%, 40 \mathrm{wt} \%, 60 \mathrm{wt} \%, 80 \mathrm{wt} \%$, and $100 \mathrm{wt} \%$ ). Figure 2 shows a schematic illustrating the overall process of membrane fabrication.

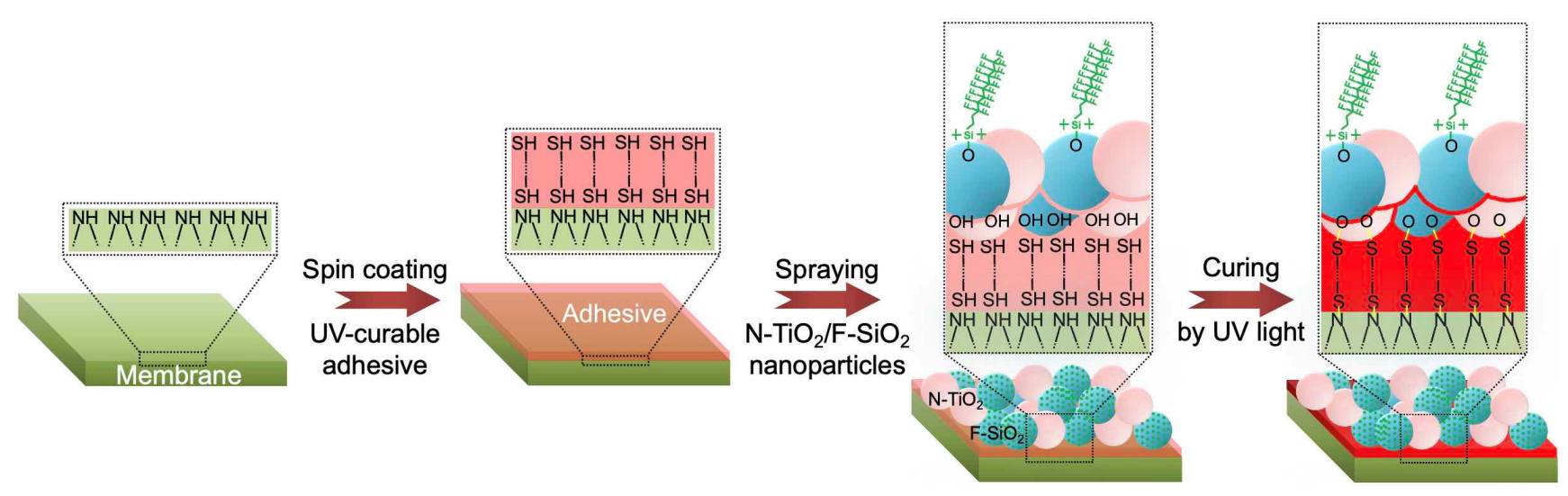

Figure 2. Schematic illustrating the fabrication of a photocatalytic membrane with hydrophilic and oleophobic wettability. A commercial filter is coated with an ultraviolet (UV) light-curable adhesive, followed by being sprayed with a mixture of $\mathrm{N}-\mathrm{TiO}_{2}$ and $\mathrm{F}-\mathrm{SiO}_{2}$ nanoparticles. The membrane was placed under UV light for curing.

The resulting membrane's surface was covered with a $\mathrm{N}-\mathrm{TiO}_{2} / \mathrm{F}_{-} \mathrm{SiO}_{2}$ coating possessing a hierarchical roughness with a re-entrant texture (Figure $3 a$ and the inset image). We measured the advancing $\left(\theta_{\text {adv }}^{*}\right)$ and receding $\left(\theta_{\text {rec }}^{*}\right)$ contact angles for the saline water $\left(1.0 \mathrm{wt} \% \mathrm{NaCl}\right.$ in DI water, $\left.\gamma_{\mathrm{lv}}=73.1 \mathrm{mN} \mathrm{m}^{-1}\right)$ and oil (n-hexadecane, $\gamma_{\mathrm{lv}}=27.5 \mathrm{mN} \mathrm{m}^{-1}$ ) in air (Figure 3b). The results indicated that a membrane coated with $\mathrm{N}-\mathrm{TiO}_{2} / \mathrm{F}-\mathrm{SiO}_{2}$ with a lower $\mathrm{N}-\mathrm{TiO}_{2}$ concentration exhibited higher contact angles for both saline water and oil. We found that when the $\mathrm{N}-\mathrm{TiO}_{2}$ concentration reached $60 \mathrm{wt} \%$, the contact angle for saline water became zero (i.e., $\theta^{*}$ saline water, adv (in-air) $=0^{\circ}$ and $\theta^{*}$ saline water, rec (in-air) $=0^{\circ}$ ), while that for oil remained constant $\left(\theta^{*}\right.$ oil, adv (in-air) $=95^{\circ} \pm 4^{\circ}, \theta^{*}$ oil, rec (in-air) $\left.=61^{\circ} \pm 3^{\circ}\right)$. Further increases in the $\mathrm{N}-\mathrm{TiO}_{2}$ concentrations resulted in sharp decreases in contact angles for oil.

Given that membrane operations in real-world applications often result in continuous immersion in liquids (e.g., water), we also measured the contact angles for oil on the membrane surface submerged in saline water (Figure 3c). The results indicated that a membrane with a lower in-air water contact angle was likely to have a higher oil contact angle when submerged in saline water. For example, a membrane coated with $\mathrm{N}$ $\mathrm{TiO}_{2} / \mathrm{F}-\mathrm{SiO}_{2}$ of $60 \mathrm{wt} \% \mathrm{~N}-\mathrm{TiO}_{2}$ (i.e., $\mathrm{N}-\mathrm{TiO}_{2} / \mathrm{F}-\mathrm{SiO}_{2}(60 \mathrm{wt} \%)$ ) exhibited contact angles of $\theta^{*}$ oil, adv (under saline water) $=175^{\circ} \pm 3^{\circ}$ and $\theta^{*}$ oil, rec (under saline water) $=171^{\circ} \pm 2^{\circ}$, while the one coated with $\mathrm{N}-\mathrm{TiO}_{2} / \mathrm{F}-\mathrm{SiO}_{2}\left(20 \mathrm{wt} \%\right.$ ) exhibited $\theta^{*}$ oil, adv (under saline water) $=169^{\circ} \pm 2^{\circ}$ and $\theta^{*}$ oil, rec (under saline water) $=161^{\circ} \pm 3^{\circ}$. The results could be further corroborated by analyzing the adhesion force of an oil droplet (n-hexadecane) placed on the membrane surface that was submerged in saline water [47] (Figure 3c). The adhesion force was $1.1 \pm 0.3 \mathrm{mN}$ on a membrane coated with $\mathrm{N}-\mathrm{TiO}_{2} / \mathrm{F}_{-} \mathrm{SiO}_{2}(60 \mathrm{wt} \%)$ and $1.7 \pm 0.4 \mathrm{mN}$ on a membrane coated with $\mathrm{N}-\mathrm{TiO}_{2} / \mathrm{F}-\mathrm{SiO}_{2}(20 \mathrm{wt} \%)$.

The membrane's wettability for saline water can affect the flux because it determines the breakthrough pressure (i.e., the maximum pressure difference across the membrane that is required for a liquid to permeate through it) [48]. We measured the flux of saline water (1.0 $\mathrm{wt} \% \mathrm{NaCl}$ in DI water) through the membranes coated with various concentrations of $\mathrm{N}-\mathrm{TiO}_{2} / \mathrm{F}_{-} \mathrm{SiO}_{2}$. A total of $100 \mathrm{~L}$ of saline water was continuously fed for $180 \mathrm{~min}$ through the membrane, which was attached to a cross-flow cell. We measured the volume of the permeate every $10 \mathrm{~min}$. It must be noted that the transmembrane pressure (TMP) (i.e., the pressure exerted across the membrane) was maintained at $\Delta p \approx 760 \mathrm{kPa} \pm 9 \mathrm{kPa}$. Figure $3 \mathrm{~d}$ shows the normalized flux $\left(J_{\mathrm{n}}\right)$ of the permeate, which is defined as $J_{\mathrm{t}} / J_{\mathrm{o}}$, where $J_{\mathrm{t}}=\Delta m / \mathrm{A} \rho \Delta t \Delta p$. Here, $\Delta m$ represents the change in the permeate mass during a particular time interval (i.e., $\Delta t=10 \mathrm{~min}), A$ is the membrane's projected area $\left(A \approx 42 \mathrm{~cm}^{2}\right), \rho$ is 
the density of the permeate $\left(\rho=1000 \mathrm{~kg} \mathrm{~m}^{-3}\right)$, and $J_{\mathrm{o}}$ symbolizes the flux over the TMP value obtained during the first three minutes of submersion. While $J_{\mathrm{n}}$ gradually decreased and reached a constant value $\left(J_{\mathrm{n}} \approx 0.59 \pm 0.04\right)$ after approximately $t=150 \mathrm{~min}$ for all membranes, one coated with $\mathrm{N}-\mathrm{TiO}_{2} / \mathrm{F}-\mathrm{SiO}_{2}$ with a higher concentration of $\mathrm{N}-\mathrm{TiO}_{2}$ showed less of a decrease in the $J_{\mathrm{n}}$ value at $t=150 \mathrm{~min}$. For example, a membrane coated with $\mathrm{N}-\mathrm{TiO}_{2} / \mathrm{F}-\mathrm{SiO}_{2}(60 \mathrm{wt} \%)$ yielded a $\mathrm{J}_{\mathrm{n}}$ value of 0.61 , whereas one coated with $\mathrm{N}-\mathrm{TiO}_{2} / \mathrm{F}-$ $\mathrm{SiO}_{2}(20 \mathrm{wt} \%)$ showed a value of 0.56 at $t=150 \mathrm{~min}$. This finding can be attributed to the difference in the breakthrough pressure of saline water [48] (Supporting Information, Section S5). Please note that the as-purchased filter and the one coated only with the cured adhesive exhibited $J_{\mathrm{n}}=0.59$ and $J_{\mathrm{n}}=0.58$, respectively, at $t=150 \mathrm{~min}$ (Figure $3 \mathrm{~d}$ ). This clearly indicates that neither the cured adhesive nor the $\mathrm{N}-\mathrm{TiO}_{2} / \mathrm{F}-\mathrm{SiO}_{2}$ coating affected the membrane's flux. We then measured the salt rejection $(\xi)$ of the membranes coated with various concentrations of $\mathrm{N}-\mathrm{TiO}_{2} / \mathrm{F}-\mathrm{SiO}_{2}$ (Supporting Information, Section S6). We also observed almost no change in the mass of the membranes after $180 \mathrm{~min}$, implying that the $\mathrm{N}-\mathrm{TiO}_{2} / \mathrm{F}-\mathrm{SiO}_{2}$ nanoparticles were securely bound to the membrane surface (Supporting Information, Section S7).
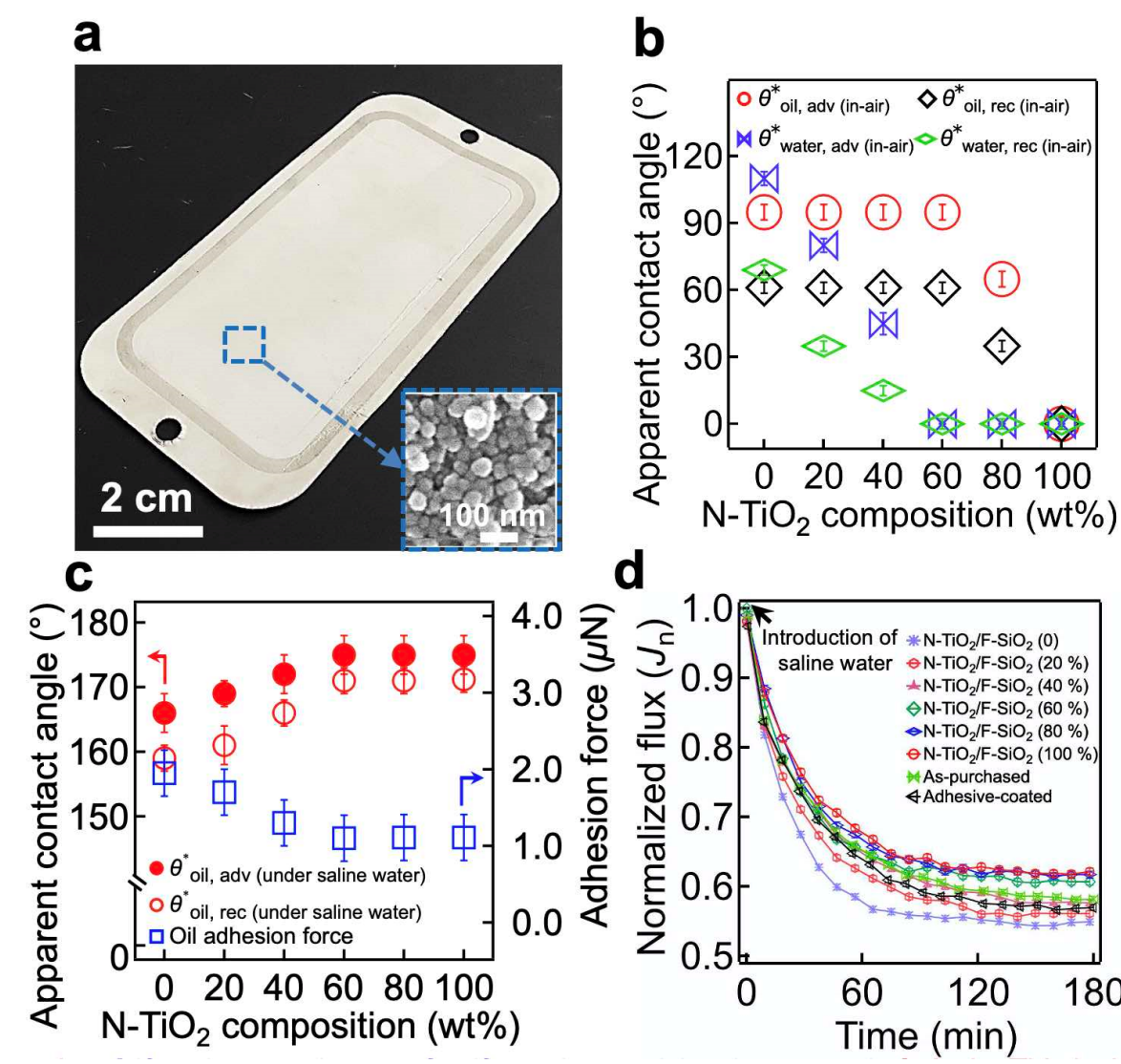

Figure 3. (a) A photograph showing a commercial filter coated with $\mathrm{N}-\mathrm{TiO}_{2} / \mathrm{F}-\mathrm{SiO}_{2}(60 \mathrm{wt} \%)$. The inset displays a scanning electron microscopy (SEM) image of the membrane surface, showing a hierarchical roughness with a re-entrant texture. (b) The measured in-air advancing and receding apparent contact angles for saline water $(1.0 \mathrm{wt} \% \mathrm{NaCl}$ in DI water) and oil (n-hexadecane) on the membrane surface, coated with $\mathrm{N}-\mathrm{TiO}_{2} / \mathrm{F}-\mathrm{SiO}_{2}$ with varied compositions. (c) The measured advancing and receding apparent contact angles, as well as the adhesion force for an oil droplet (n-hexadecane) on the membrane surface, coated with $\mathrm{N}-\mathrm{TiO}_{2} / \mathrm{F}-\mathrm{SiO}_{2}$ with various compositions submerged in saline water. (d) The normalized flux $\left(J_{n}\right)$ of the permeate through the membranes coated with $\mathrm{N}-\mathrm{TiO}_{2} / \mathrm{F}_{-} \mathrm{SiO}_{2}$ with varied compositions. The data for the as-purchased commercial filter and for the one coated only with cured adhesive were also provided for comparison. 
3.3. Continuous Separation and Desalination of an Oil-Saline Water Mixture and Simultaneous Photocatalytic Degradation of Organic Foulants upon Visible Light Irradiation

The photocatalytic capability of our coating, in conjunction with its hydrophilic and oleophobic wettability both in air and under saline water, enables the membrane to separate and desalinate an oil-saline water mixture while simultaneously degrading the organic foulants adsorbed onto the membrane surface during exposure to visible light irradiation $[49,50]$. To demonstrate this, we mounted the membrane to an apparatus and irradiated it with visible light (Figure 4a). The feed oil-saline water mixture was continuously fed to the cell while the water-rich permeate continuously passed through the membrane and collected in a permeate tank. Here, we utilized an emulsion of n-hexadecane in water (10:90 vol:vol, n-hexadecane:water) dissolved with salt $(1.0 \mathrm{wt} \% \mathrm{NaCl}$ with respect to the water mass) that was stabilized by sodium dodecyl sulfate (SDS) (see Section 2). We tested membranes coated with various concentrations of $\mathrm{N}-\mathrm{TiO}_{2} / \mathrm{SiO}_{2}$. Of note, all membranes were prewetted by soaking them in saline water $(1.0 \mathrm{wt} \% \mathrm{NaCl})$ for $150 \mathrm{~min}$ to obtain a constant flux over the TMP $\left(J_{\text {prewet }}\right)$ before being subjected to the feed emulsion.

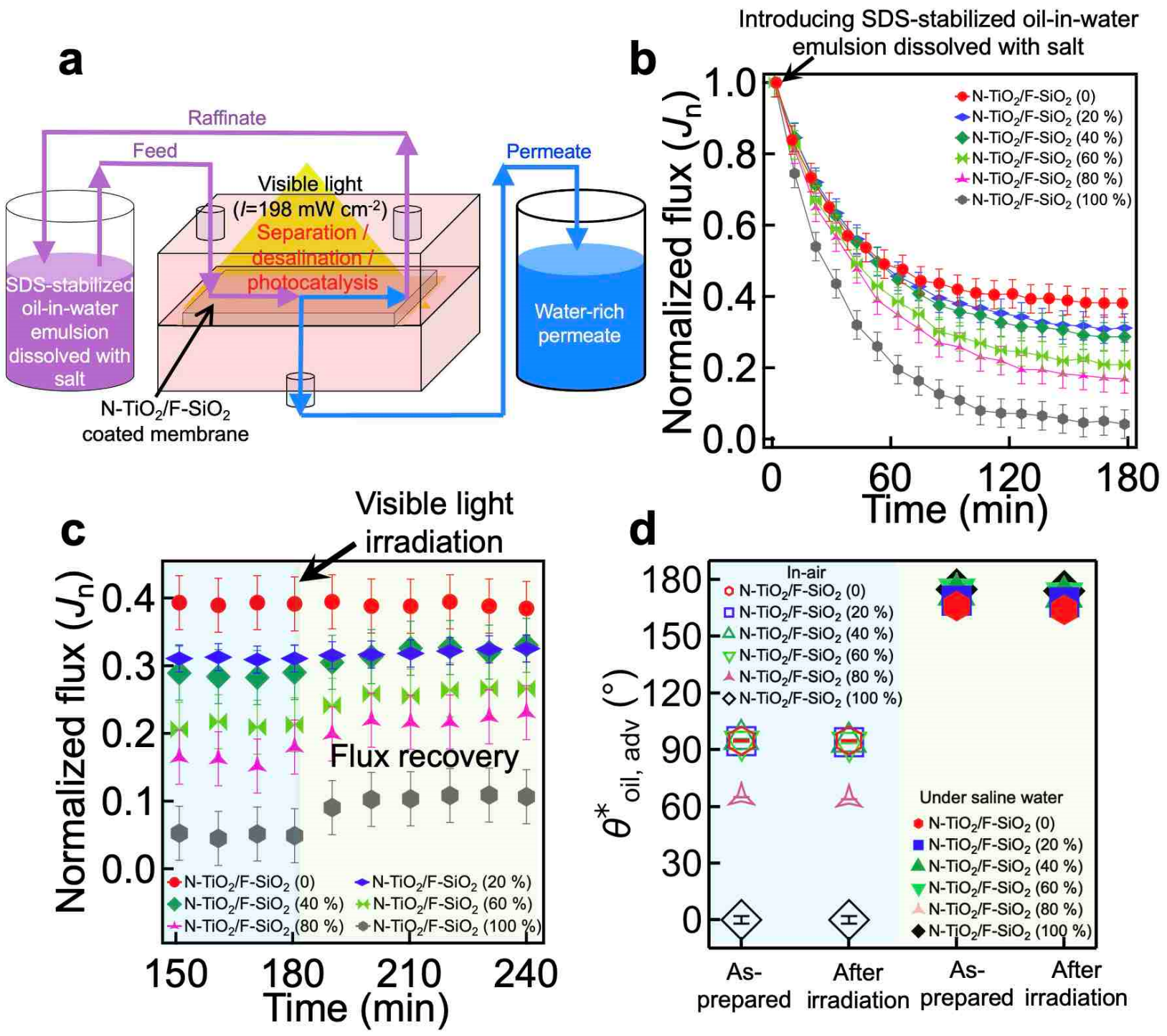

Figure 4. (a) Schematic illustrating the cross-flow apparatus that enables continuous separation and desalination of an oil-saline water mixture and simultaneous photocatalytic degradation of the organic foulants adsorbed onto the membrane's 
surface upon visible light irradiation. (b) The normalized flux $\left(J_{n}\right)$ of the water-rich permeate through the membranes coated with $\mathrm{N}-\mathrm{TiO}_{2} / \mathrm{F}-\mathrm{SiO}_{2}$ with varied compositions that are subjected to sodium dodecyl sulfate (SDS)-stabilized nhexadecane-in-water emulsion (10:90 vol:vol, n-hexadecane:water) dissolved with salt (1.0 wt $\% \mathrm{NaCl}$ with respect to the water mass). (c) The normalized flux $\left(J_{n}\right)$ of the water-rich permeate through the membranes being irradiated by visible light $\left(I \approx 198 \mathrm{~mW} \mathrm{~cm}^{-2}\right)$. (d) The apparent contact angles for oil (n-hexadecane) droplets on the membranes in air and under saline water before and after visible light irradiation for $120 \mathrm{~min}$. The data of the as-prepared membranes are also shown for comparison.

When the feed emulsion was introduced, the flux of the water-rich permeate began to rapidly decrease due to membrane fouling by the oil (Figure $4 \mathrm{~b}$ and Table 1 ). This is a consequence of the oil's adsorption to the membrane surface, which can hamper the permeation of water and cause a rapid decline in the flux. Note that $J_{\mathrm{n}}$ is defined as $J_{\mathrm{t}} / J_{\text {prewet }}$. According to our findings, an $\mathrm{N}-\mathrm{TiO}_{2} / \mathrm{F}_{-} \mathrm{SiO}_{2}$-coated membrane with a higher $\mathrm{N}-\mathrm{TiO}_{2}$ composition exhibited a steeper decrease in flux. For example, when a membrane was coated with $\mathrm{N}-\mathrm{TiO}_{2} / \mathrm{F}_{-}-\mathrm{SiO}_{2}(80 \mathrm{wt} \%), J_{\mathrm{n}} \approx 0.17\left(\mathrm{~J}_{\mathrm{t}} \approx 0.0135 \mathrm{Lm}^{-2} \mathrm{~h}^{-1} \mathrm{kPa}^{-1}\right)$. However, when it was coated with $\mathrm{N}-\mathrm{TiO}_{2} / \mathrm{F}-\mathrm{SiO}_{2}(20 \mathrm{wt} \%), J_{\mathrm{n}} \approx 0.30\left(\mathrm{~J}_{\mathrm{t}} \approx 0.0163 \mathrm{Lm}^{-2} \mathrm{~h}^{-1} \mathrm{kPa}^{-1}\right)$ at $t=180 \mathrm{~min}$. This can be primarily attributed to the fact that $\mathrm{N}-\mathrm{TiO}_{2}$ is more vulnerable to oil adsorption [51], while F-SiO ${ }_{2}$ can repel it [52] (Supporting Movie S1). Note that such a rapid flux decline in the membranes after the introduction of an oil-water mixture has been reported previously $[53,54]$. Despite the membranes' decline in flux, the concentration of oil in the permeate remained very low (i.e., $<0.1 \mathrm{wt} \%$; see Supporting Information, Section S8).

Table 1. The values of the flux of the water-rich permeate through the membranes coated with N$\mathrm{TiO}_{2} / \mathrm{F}-\mathrm{SiO}_{2}$ with varied compositions that were subjected to sodium dodecyl sulfate (SDS)-stabilized n-hexadecane-in-water emulsion (10:90 vol:vol, n-hexadecane:water) dissolved with salt (1.0 wt $\%$ $\mathrm{NaCl}$ with respect to the water mass).

\begin{tabular}{|c|c|c|}
\hline $\mathrm{N}-\mathrm{TiO}_{2} / \mathrm{F}_{-} \mathrm{SiO}_{2}$ Compositions & $\begin{array}{c}\text { Flux at } \mathrm{t}=0 \\
\left(J_{\mathrm{o}}\right)\left(\mathrm{Lm}^{-2} \mathrm{~h}^{-1} \mathrm{kPa}^{-1}\right)\end{array}$ & $\begin{array}{l}\text { Flux at } t=180 \mathrm{~min} \\
\left(J_{t}\right)\left(\mathrm{Lm}^{-2} \mathrm{~h}^{-1} \mathrm{kPa}^{-1}\right)\end{array}$ \\
\hline $\mathrm{N}-\mathrm{TiO}_{2} / \mathrm{F}-\mathrm{SiO}_{2}(0)$ & 0.0467 & 0.0177 \\
\hline $\mathrm{N}-\mathrm{TiO}_{2} / \mathrm{F}-\mathrm{SiO}_{2}(20 \mathrm{wt} \%)$ & 0.0547 & 0.0163 \\
\hline $\mathrm{N}-\mathrm{TiO}_{2} / \mathrm{F}-\mathrm{SiO}_{2}(40 \mathrm{wt} \%)$ & 0.0627 & 0.0174 \\
\hline $\mathrm{N}-\mathrm{TiO}_{2} / \mathrm{F}-\mathrm{SiO}_{2}(60 \mathrm{wt} \%)$ & 0.0786 & 0.0157 \\
\hline $\mathrm{N}-\mathrm{TiO}_{2} / \mathrm{F}-\mathrm{SiO}_{2}(80 \mathrm{wt} \%)$ & 0.0826 & 0.0135 \\
\hline $\mathrm{N}-\mathrm{TiO}_{2} / \mathrm{F}-\mathrm{SiO}_{2}(100 \mathrm{wt} \%)$ & 0.0826 & 0.0033 \\
\hline
\end{tabular}

When the water-rich permeate flux reached a constant value at $t=180 \mathrm{~min}$, we began to irradiate the membrane surface with visible light $\left(I \approx 198 \mathrm{~mW} \mathrm{~cm}^{-2}\right)$ to induce photocatalytic degradation of the surface's adsorbed oil. This was a result of electron-hole $\left(\mathrm{e}^{-}-\mathrm{h}^{+}\right)$pairs generated upon light irradiation with an energy greater than the bandgap energy of the photocatalyst (e.g., $\mathrm{N}-\mathrm{TiO}_{2}$ ) [55]. The electrons and holes can react with the ambient molecules (e.g., oxygen or water) and generate reactive radicals such as hydroxyl, which can remove organic contaminants such as oil by chemical oxidation (or reduction) [31]. The membrane was then continuously subjected to a fresh feed emulsion. We observed that a membrane coated with $\mathrm{N}-\mathrm{TiO}_{2} / \mathrm{F}_{-} \mathrm{SiO}_{2}$ with a higher concentration of $\mathrm{N}-\mathrm{TiO}_{2}$ caused a more significant increase in the $J_{\mathrm{n}}$ value, which was a direct result of the photocatalysis-driven recovery of the clean membrane surface that exhibited a lower breakthrough pressure for saline water (Figure $4 \mathrm{c}$ and Table 2). For example, a membrane coated with $\mathrm{N}-\mathrm{TiO}_{2} / \mathrm{F}-\mathrm{SiO}_{2}(80 \mathrm{wt} \%)$ yielded $J_{\mathrm{n}} \approx 0.24\left(\mathrm{~J}_{\mathrm{t}} \approx 0.0190 \mathrm{Lm}^{-2} \mathrm{~h}^{-1} \mathrm{kPa}^{-1}\right)$, while the one coated with $\mathrm{N}-\mathrm{TiO}_{2} / \mathrm{F}_{-} \mathrm{SiO}_{2}(20 \mathrm{wt} \%)$ exhibited $J_{\mathrm{n}} \approx 0.31\left(J_{\mathrm{t}} \approx 0.0174 \mathrm{Lm}^{-2} \mathrm{~h}^{-1} \mathrm{kPa}^{-1}\right)$ after $60 \mathrm{~min}$ of irradiation. 
Table 2. The values of the flux of the water-rich permeate through the membranes coated with N$\mathrm{TiO}_{2} / \mathrm{F}-\mathrm{SiO}_{2}$ with varied compositions after $60 \mathrm{~min}$ of irradiation with visible light $\left(I \approx 198 \mathrm{~mW} \mathrm{~cm}^{-2}\right)$.

\begin{tabular}{|c|c|c|}
\hline $\mathrm{N}-\mathrm{TiO}_{2} / \mathrm{F}_{-} \mathrm{SiO}_{2}$ Compositions & $\begin{array}{c}\text { Flux at } \mathrm{t}=180 \mathrm{~min} \\
\text { (before Irradiation) } \\
\left(\mathrm{Lm}^{-2} \mathrm{~h}^{-1} \mathbf{k P a}^{-1}\right)\end{array}$ & $\begin{array}{c}\text { Flux at } t=240 \text { min (after } \\
60 \text { min of Irradiation) } \\
\left(\mathrm{Lm}^{-2} \mathrm{~h}^{-1} \mathrm{kPa}^{-1}\right)\end{array}$ \\
\hline $\mathrm{N}-\mathrm{TiO}_{2} / \mathrm{F}-\mathrm{SiO}_{2}(0)$ & 0.0177 & 0.0177 \\
\hline $\mathrm{N}-\mathrm{TiO}_{2} / \mathrm{F}-\mathrm{SiO}_{2}(20 \mathrm{wt} \%)$ & 0.0163 & 0.0174 \\
\hline $\mathrm{N}-\mathrm{TiO}_{2} / \mathrm{F}-\mathrm{SiO}_{2}(40 \mathrm{wt} \%)$ & 0.0174 & 0.0200 \\
\hline $\mathrm{N}-\mathrm{TiO}_{2} / \mathrm{F}-\mathrm{SiO}_{2}(60 \mathrm{wt} \%)$ & 0.0157 & 0.0212 \\
\hline $\mathrm{N}-\mathrm{TiO}_{2} / \mathrm{F}-\mathrm{SiO}_{2}(80 \mathrm{wt} \%)$ & 0.0135 & 0.0190 \\
\hline $\mathrm{N}-\mathrm{TiO}_{2} / \mathrm{F}-\mathrm{SiO}_{2}(100 \mathrm{wt} \%)$ & 0.0033 & 0.0090 \\
\hline
\end{tabular}

While an in situ photocatalysis-driven recovery of the clean membrane surface is presented in this work, a majority of the previous studies have demonstrated this ex situ. For example, Zhang et al. [33] synthesized an electrospun membrane anchored with photocatalytic $\beta-\mathrm{FeOOH}$ nanorods. The membrane demonstrated that it could photocatalytically degrade the surface adsorbed organic matter and recover its flux upon visible light irradiation after $40 \mathrm{~min}$. Peyravi et al. [56] incorporated photocatalytic $\mathrm{TiO}_{2} /$ zeolite into a composite membrane and demonstrated $\approx 83.6 \%$ flux recovery under UV irradiation. Liu et al. [34] fabricated a membrane utilizing $\mathrm{TiO}_{2} /$ carbon nitride nanosheets and showed membrane surface cleaning with a flux recovery ratio of $>95 \%$. In addition, Kovács et al. [57] demonstrated that a $\mathrm{TiO}_{2}$-coated ultrafiltration membrane could almost completely recover its original flux after $1 \mathrm{~h}$ of UV irradiation. Furthermore, Xie et al. [58] fabricated a photocatalytic membrane using $\beta-\mathrm{FeOOH}$, which demonstrated $>98 \%$ flux recovery within $10 \mathrm{~min}$ under visible light.

We also measured the contact angles for oil and saline water after $60 \mathrm{~min}$ of visible light irradiation and found that they remained unchanged (Figure 4d). This indicates that the photocatalytic reaction taking place within the $\mathrm{N}-\mathrm{TiO}_{2}$ did not affect the perfluoro silane molecules grafted to the $\mathrm{SiO}_{2}$ (Supporting Information, Section S9). Moreover, both the salt rejection $(\tilde{\xi})$ of the membranes and the cured adhesive layer remained nearly unchanged (Supporting Information, Section S10).

\section{Conclusions}

In summary, we have developed a photocatalytic coating with hydrophilic and oleophobic wettability by intercalating a mixture of visible light-responsive $\mathrm{N}-\mathrm{TiO}_{2}$ and low surface energy $\mathrm{F}-\mathrm{SiO}_{2}$ nanoparticles. We tested the feasibility of our membrane coating by spraying it on a commercial membrane surface with UV-curable adhesive. Subsequent irradiation with UV light resulted in a chemically heterogeneous surface with intercalating high surface energy $\left(\mathrm{N}-\mathrm{TiO}_{2}\right)$ and low surface energy $\left(\mathrm{F}-\mathrm{SiO}_{2}\right)$ regions that were securely bound to the surface. Our membrane could recover the flux upon visible light irradiation. We attributed this to the photocatalytic degradation of the surface adsorbed oil when placed under visible light irradiation. Such photocatalytic degradation did not compromise the wettability or integrity of the membrane due to the robust chemistry of the adhesive. We engineered an apparatus that enabled the continuous separation and desalination of a surfactant-stabilized oil-in-water emulsion that was dissolved with salt and the photocatalytic degradation of organic substances that were adsorbed on the coated membrane surface when it was exposed to visible light irradiation. It was found that the coated membrane was able to recover its permeate flux in situ when placed under visible light irradiation. We envision that our membrane will have a wide range of practical applications, including wastewater treatment, fuel purification, and desalinating brackish water. 
Supplementary Materials: The following are available online at https:/ / www.mdpi.com/article /

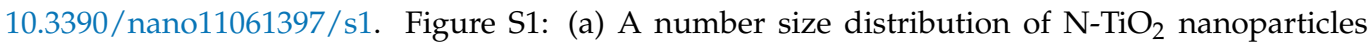
obtained by utilizing the DLS method. $(b, c)$ Transmission electron microscopy (TEM) image of $\mathrm{N}-\mathrm{TiO}_{2}$ nanoparticles (b) and high-resolution TEM image showing $\mathrm{N}-\mathrm{TiO}_{2}$ lattice structure with an average spacing of $\approx 0.35 \mathrm{~nm}$ (c). Figure S2: XRD pattern of $\mathrm{N}-\mathrm{TiO}_{2}$ nanoparticles synthesized by utilizing a molar ratio of TEA and TBOT of 2.0. For comparison, the XRD pattern of a neat $\mathrm{TiO}_{2}$ is shown. Figure S3: UV-Vis absorption spectra of water solutions dissolved with Solvent Blue 38 dye (concentration $=0.5 \mathrm{wt} \%$ ) and $\mathrm{N}-\mathrm{TiO}_{2}$ (concentration $=0.5 \mathrm{wt} \%$ ) after $2 \mathrm{~h}$ of visible light irradiation with varied intensity. The UV-Vis absorption spectra of the water solution dissolved with Solvent Blue 38 dye (concentration $=0.5 \mathrm{wt} \%$ ) and $\mathrm{N}-\mathrm{TiO}_{2}$ (concentration $=0.5 \mathrm{wt} \%$ ) after $10 \mathrm{~h}$ in the dark is also provided. Figure S4: (a) Schematic illustrating the synthesis of $\mathrm{F}_{-} \mathrm{SiO}_{2}$ nanoparticles by utilizing tetraethyl orthosilicate (TEOS) as a $\mathrm{SiO}_{2}$ precursor and $1 \mathrm{H}, 1 \mathrm{H}, 2 \mathrm{H}, 2 \mathrm{H}$-perfluorodecyl trichlorosilane (i.e., perfluoro silane). (b) A number size distribution of $\mathrm{F}_{-} \mathrm{SiO}_{2}$ nanoparticles, obtained by utilizing the DLS method. Figure S5: A plot of the measured breakthrough pressure for saline water $\left(1.0 \mathrm{wt} \% \mathrm{NaCl}\right.$ in DI water) of the membranes coated with $\mathrm{N}-\mathrm{TiO}_{2} / \mathrm{F}-\mathrm{SiO}_{2}$ with varied compositions. Figure S6: (a) The calibration curve established by calculating the electrical conductivity of water as a function of salt $(\mathrm{NaCl})$ concentrations. The inset shows zoomed-in electrical conductivity data in the $\mathrm{NaCl}$ concentration range of $0.00-0.20 \mathrm{wt} \%$. (b) The salt rejection ( $\xi$ ) data of the membranes coated with $\mathrm{N}-\mathrm{TiO}_{2} / \mathrm{F}_{-} \mathrm{SiO}_{2}$ with varied compositions. The data of the as-purchased commercial filter and that coated only with cured adhesive are also provided for comparison. Figure S7: The mass loss of the membranes coated with $\mathrm{N}-\mathrm{TiO}_{2} / \mathrm{F}-\mathrm{SiO}_{2}$ with varied compositions after $180 \mathrm{~min}$ of desalination of saline water at a flow rate of $1.5 \mathrm{~L} \mathrm{~min}^{-1}$. For comparison, the results obtained by utilizing the membranes without cured adhesive are also shown. Figure S8: The TGA data of the water-rich permeates after the separation of SDS-stabilized oil-in-water emulsion dissolved with $\mathrm{NaCl}$ (1.0 $\mathrm{wt} \%$ with respect to the water mass) through the membranes coated $\mathrm{N}-\mathrm{TiO}_{2} / \mathrm{F}-\mathrm{SiO}_{2}$ with varied compositions. Figure S9: The FT-IR spectra of a membrane surface coated with N$\mathrm{TiO}_{2} / \mathrm{F}_{-} \mathrm{SiO}_{2}\left(60 \mathrm{wt} \%\right.$ ) after $120 \mathrm{~min}$ of visible light irradiation with an intensity of $\approx 198 \mathrm{~mW} \mathrm{~cm}^{-2}$. For comparison, the FT-IR spectra of the as-prepared membrane surface is shown. Figure S10: The FT-IR spectra of the cured adhesive after $180 \mathrm{~min}$ of visible light-driven photocatalysis by N$\mathrm{TiO}_{2}\left(I \approx 198 \mathrm{~mW} \mathrm{~cm}{ }^{-2}\right)$. For comparison, the FT-IR spectra of the as-prepared adhesive is also shown. Figure S11: The salt rejection $(\xi)$ of the membranes coated with $\mathrm{N}-\mathrm{TiO}_{2} / \mathrm{F}_{-} \mathrm{SiO}_{2}$ with varied compositions after exposure to $60 \mathrm{~min}$ of visible light irradiation.

Author Contributions: B.S. and M.E. performed the experiments, analyzed the data, and wrote the manuscript. G.K. conceived the project, designed the experiments, and wrote the manuscript. All authors have read and agreed to the published version of the manuscript.

Funding: This research was supported by the U.S. Department of Interior-Bureau of Reclamation [grant number: R17AC00132], National Science Foundation RET Site: Exploring Career Opportunities through Water-Themed Engineering Research (ECO-WaTER) [grant number: 1801710], and the National Science Foundation [grant number: CBET-1944314].

Data Availability Statement: The datasets generated during and/or analyzed during this study are not publicly available but are available from the corresponding author on reasonable request.

Conflicts of Interest: The authors declare that they have no known competing financial interests or personal relationships that could have appeared to influence the work reported in this paper.

\section{References}

1. Eseev, M.; Goshev, A.; Kapustin, S.; Tsykareva, Y. Creation of Superhydrophobic Coatings Based on MWCNTs Xerogel. Nanomaterials 2019, 9, 1584. [CrossRef]

2. Dong, S.; Wang, Z.; An, L.; Li, Y.; Wang, B.; Ji, H.; Wang, H. Facile Fabrication of a Superhydrophobic Surface with Robust Micro-/Nanoscale Hierarchical Structures on Titanium Substrate. Nanomaterials 2020, 10, 1509. [CrossRef] [PubMed]

3. Li, J.; Qin, Q.H.; Shah, A.; Ras, R.H.A.; Tian, X.; Jokinen, V. Oil droplet self-transportation on oleophobic surfaces. Sci. Adv. 2016, 2, e1600148. [CrossRef] [PubMed]

4. Geng, H.; Bai, H.; Fan, Y.; Wang, S.; Ba, T.; Yu, C.; Cao, M.; Jiang, L. Unidirectional water delivery on a superhydrophilic surface with two-dimensional asymmetrical wettability barriers. Mater. Horiz. 2018, 5, 303-308. [CrossRef]

5. Lv, J.; Gong, Z.; He, Z.; Yang, J.; Chen, Y.; Tang, C.; Liu, Y.; Fan, M.; Lau, W.-M. 3D printing of a mechanically durable superhydrophobic porous membrane for oil-water separation. J. Mater. Chem. A 2017, 5, 12435-12444. [CrossRef] 
6. Sun, S.; Zhu, L.; Liu, X.; Wu, L.; Dai, K.; Liu, C.; Shen, C.; Guo, X.; Zheng, G.; Guo, Z. Superhydrophobic Shish-kebab Membrane with Self-Cleaning and Oil/Water Separation Properties. ACS Sustain. Chem. Eng. 2018, 6, 9866-9875. [CrossRef]

7. Kwon, G.; Post, E.; Tuteja, A. Membranes with selective wettability for the separation of oil-water mixtures. MRS Commun. 2015 5, 475-494. [CrossRef]

8. Law, K.Y.; Zhao, H. Surface Wetting: Characterization, Contact Angle, and Fundamentals; Springer International Publishing: New York, NY, USA, 2015; pp. 95-150.

9. Ezazi, M.; Shrestha, B.; Klein, N.; Lee, D.H.; Seo, S.; Kwon, G. Self-Healable Superomniphobic Surfaces for Corrosion Protection. ACS Appl. Mater. Interfaces 2019, 11, 30240-30246. [CrossRef] [PubMed]

10. Kota, A.K.; Kwon, G.; Tuteja, A. The design and applications of superomniphobic surfaces. NPG Asia Mater. 2014, 6, e109. [CrossRef]

11. Vahabi, H.; Wang, W.; Popat, K.C.; Kwon, G.; Holland, T.B.; Kota, A.K. Metallic superhydrophobic surfaces via thermal sensitization. Appl. Phys. Lett. 2017, 110, 251602. [CrossRef]

12. Brown, P.S.; Bhushan, B. Mechanically durable, superomniphobic coatings prepared by layer-by-layer technique for self-cleaning and anti-smudge. J. Colloid Interface Sci. 2015, 456, 210-218. [CrossRef]

13. Moiz, A.; Padhye, R.; Wang, X. Durable Superomniphobic Surface on Cotton Fabrics via Coating of Silicone Rubber and Fluoropolymers. Coatings 2018, 8, 104. [CrossRef]

14. Zhang, H.; Ji, X.; Liu, L.; Ren, J.; Tao, F.; Qiao, C. Versatile, mechanochemically robust, sprayed superomniphobic coating enabling low surface tension and high viscous organic liquid bouncing. Chem. Eng. J. 2020, 402, 126160. [CrossRef]

15. Vilčnik, A.; Jerman, I.; Vuk, A.; Šurca Koželj, M.; Orel, B.; Tomšič, B.; Simončič, B.; Kovač, J. Structural Properties and Antibacterial Effects of Hydrophobic and Oleophobic Sol-Gel Coatings for Cotton Fabrics. Langmuir 2009, 25, 5869-5880. [CrossRef] [PubMed]

16. Hayn, R.A.; Owens, J.R.; Boyer, S.A.; McDonald, R.S.; Lee, H.J. Preparation of highly hydrophobic and oleophobic textile surfaces using microwave-promoted silane coupling. J. Mater. Sci. 2010, 46, 2503-2509. [CrossRef]

17. Wang, W.; Salazar, J.; Vahabi, H.; Joshi-Imre, A.; Voit, W.E.; Kota, A.K. Metamorphic Superomniphobic Surfaces. Adv. Mater. 2017, 29, 1700295. [CrossRef] [PubMed]

18. Yun, G.-T.; Jung, W.-B.; Oh, M.S.; Jang, G.M.; Baek, J.; Kim, N.I.; Im, S.G.; Jung, H.-T. Springtail-inspired superomniphobic surface with extreme pressure resistance. Sci. Adv. 2018, 4, eaat4978. [CrossRef]

19. Mertens, M.; Mohr, M.; Bruehne, K.; Fecht, H.-J.; Łojkowski, M.; Święszkowski, W.; Łojkowski, W. Patterned hydrophobic and hydrophilic surfaces of ultra-smooth nanocrystalline diamond layers. Appl. Surf. Sci. 2016, 390, 526-530. [CrossRef]

20. Howarter, J.A.; Youngblood, J.P. Self-Cleaning and Next Generation Anti-Fog Surfaces and Coatings. Macromol. Rapid Commun. 2008, 29, 455-466. [CrossRef]

21. Jayaramulu, K.; Geyer, F.; Petr, M.; Zboril, R.; Vollmer, D.; Fischer, R.A. Shape Controlled Hierarchical Porous Hydrophobic/Oleophilic Metal-Organic Nanofibrous Gel Composites for Oil Adsorption. Adv. Mater. 2017, 29, 1605307. [CrossRef]

22. Brown, P.; Atkinson, O.D.L.A.; Badyal, J.P.S. Ultrafast Oleophobic-Hydrophilic Switching Surfaces for Antifogging, Self-Cleaning, and Oil-Water Separation. ACS Appl. Mater. Interfaces 2014, 6, 7504-7511. [CrossRef]

23. Qing, W.; Liu, F.; Yao, H.; Sun, S.; Chen, C.; Zhang, W. Functional catalytic membrane development: A review of catalyst coating techniques. Adv. Colloid Interface Sci. 2020, 282, 102207. [CrossRef]

24. Li, Q.; Zhao, T.; Li, M.; Li, W.; Yang, B.; Qin, D.; Lv, K.; Wang, X.; Wu, L.; Wu, X.; et al. One-step construction of Pickering emulsion via commercial TiO2 nanoparticles for photocatalytic dye degradation. Appl. Catal. B Environ. 2019, 249, 1-8. [CrossRef]

25. Li, X.; Wu, X.; Liu, S.; Li, Y.; Fan, J.; Lv, K. Effects of fluorine on photocatalysis. Chin. J. Catal. 2020, 41, 1451-1467. [CrossRef]

26. Coelho, F.E.B.; Gionco, C.; Paganini, M.C.; Calza, P.; Magnacca, G. Control of Membrane Fouling in Organics Filtration Using Ce-Doped Zirconia and Visible Light. Nanomaterials 2019, 9, 534. [CrossRef]

27. Liu, T.; Wang, L.; Liu, X.; Sun, C.; Lv, Y.; Miao, R.; Wang, X. Dynamic photocatalytic membrane coated with ZnIn2S4 for enhanced photocatalytic performance and antifouling property. Chem. Eng. J. 2020, 379, 122379. [CrossRef]

28. Qahtan, T.F.; Gondal, M.A.; Dastageer, M.A.; Kwon, G.; Ezazi, M.; Al-Kuban, M.Z. Thermally Sensitized Membranes for Crude Oil-Water Remediation under Visible Light. ACS Appl. Mater. Interfaces 2020, 12, 48572-48579. [CrossRef]

29. Lv, Y.; Zhang, C.; He, A.; Yang, S.-J.; Wu, G.-P.; Darling, S.B.; Xu, Z.-K. Photocatalytic Nanofiltration Membranes with Self-Cleaning Property for Wastewater Treatment. Adv. Funct. Mater. 2017, 27, 1700251. [CrossRef]

30. Yu, J.C.; Ho, W.; Lin, J.; Yip, H.; Wong, P.K. Photocatalytic Activity, Antibacterial Effect, and Photoinduced Hydrophilicity of TiO2Films Coated on a Stainless Steel Substrate. Environ. Sci. Technol. 2003, 37, 2296-2301. [CrossRef]

31. Ezazi, M.; Shrestha, B.; Kim, S.; Jeong, B.; Gorney, J.; Hutchison, K.; Lee, D.H.; Kwon, G. Selective Wettability Membrane for Continuous Oil-Water Separation and In Situ Visible Light-Driven Photocatalytic Purification of Water. Glob. Chall. 2020, 4, 2000009. [CrossRef]

32. Song, S.; Yang, H.; Zhou, C.; Cheng, J.; Jiang, Z.; Lu, Z.; Miao, J. Underwater superoleophobic mesh based on BiVO 4 nanoparticles with sunlight-driven self-cleaning property for oil/water separation. Chem. Eng. J. 2017, 320, 342-351. [CrossRef]

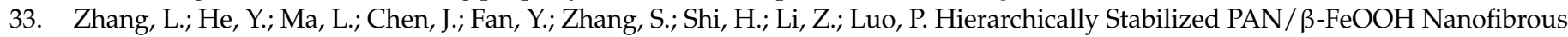
Membrane for Efficient Water Purification with Excellent Antifouling Performance and Robust Solvent Resistance. ACS Appl. Mater. Interfaces 2019, 11, 34487-34496. [CrossRef]

34. Liu, Y.; Su, Y.; Guan, J.; Cao, J.; Zhang, R.; He, M.; Gao, K.; Zhou, L.; Jiang, Z. 2D Heterostructure Membranes with Sunlight-Driven Self-Cleaning Ability for Highly Efficient Oil-Water Separation. Adv. Funct. Mater. 2018, 28, 1706545. [CrossRef] 
35. Zhao, J.; Zhu, W.; Wang, X.; Liu, L.; Yu, J.; Ding, B. Environmentally benign modification of breathable nanofibrous membranes exhibiting superior waterproof and photocatalytic self-cleaning properties. Nanoscale Horiz. 2019, 4, 867-873. [CrossRef]

36. Luster, E.; Avisar, D.; Horovitz, I.; Lozzi, L.; Baker, M.A.; Grilli, R.; Mamane, H. N-Doped TiO 2 -Coated Ceramic Membrane for Carbamazepine Degradation in Different Water Qualities. Nanomaterials 2017, 7, 206. [CrossRef]

37. Wang, D.; Liu, Y.; Liu, X.; Zhou, F.; Liu, W.; Xue, Q. Towards a tunable and switchable water adhesion on a $\mathrm{TiO}_{2}$ nanotube film with patterned wettability. Chem. Commun. 2009, 2009, 7018-7020. [CrossRef]

38. Horovitz, I.; Gitis, V.; Avisar, D.; Mamane, H. Ceramic-based photocatalytic membrane reactors for water treatment-Where to next? Rev. Chem. Eng. 2020, 36, 593-622. [CrossRef]

39. Di Valentin, C.; Finazzi, E.; Pacchioni, G.; Selloni, A.; Livraghi, S.; Paganini, M.C.; Giamello, E. N-doped TiO 2 : Theory and experiment. Chem. Phys. 2007, 339, 44-56. [CrossRef]

40. Premkumar, J. Development of Super-Hydrophilicity on Nitrogen-Doped $\mathrm{TiO}_{2}$ Thin Film Surface by Photoelectrochemical Method under Visible Light. Chem. Mater. 2004, 16, 3980-3981. [CrossRef]

41. Brassard, J.-D.; Sarkar, D.K.; Perron, J. Synthesis of Monodisperse Fluorinated Silica Nanoparticles and Their Superhydrophobic Thin Films. ACS Appl. Mater. Interfaces 2011, 3, 3583-3588. [CrossRef]

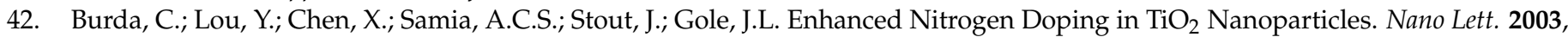
3, 1049-1051. [CrossRef]

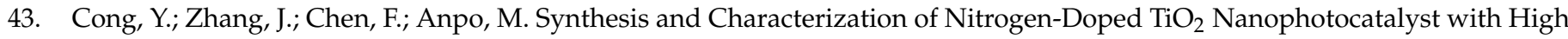
Visible Light Activity. J. Phys. Chem. C 2007, 111, 6976-6982. [CrossRef]

44. Yang, G.; Jiang, Z.; Shi, H.; Xiao, T.; Yan, Z. Preparation of highly visible-light active N-doped TiO 2 photocatalyst. J. Mater. Chem. 2010, 20, 5301-5309. [CrossRef]

45. Stöber, W.; Fink, A.; Bohn, E. Controlled growth of monodisperse silica spheres in the micron size range. J. Colloid Interface Sci. 1968, 26, 62-69. [CrossRef]

46. Zhang, Z.; Zhang, W.; Lichtfouse, E. Membranes for Environmental Applications; Springer International Publishing: New York, NY, USA, 2020; pp. 200-220.

47. Furmidge, C. Studies at phase interfaces. I. The sliding of liquid drops on solid surfaces and a theory for spray retention. J. Colloid Sci. 1962, 17, 309-324. [CrossRef]

48. Tuteja, A.; Choi, W.; Ma, M.; Mabry, J.M.; Mazzella, S.A.; Rutledge, G.C.; McKinley, G.H.; Cohen, R.E. Designing Superoleophobic Surfaces. Science 2007, 318, 1618-1622. [CrossRef] [PubMed]

49. Kwon, G.; Kota, A.K.; Li, Y.; Sohani, A.; Mabry, J.M.; Tuteja, A. On-Demand Separation of Oil-Water Mixtures. Adv. Mater. 2012, 24, 3666-3671. [CrossRef]

50. Kwon, G.; Panchanathan, D.; Mahmoudi, S.R.; Gondal, M.A.; McKinley, G.H.; Varanasi, K.K. Visible light guided manipulation of liquid wettability on photoresponsive surfaces. Nat. Commun. 2017, 8, 14968. [CrossRef] [PubMed]

51. Vaiano, V.; Sacco, O.; Sannino, D.; Navarra, W.; Daniel, C.; Venditto, V. Influence of aggregate size on photoactivity of N-doped TiO2 particles in aqueous suspensions under visible light irradiation. J. Photochem. Photobiol. A Chem. 2017, 336, 191-197. [CrossRef]

52. Hsieh, C.-T.; Chang, B.-S.; Lin, J.-Y. Improvement of water and oil repellency on wood substrates by using fluorinated silica nanocoating. Appl. Surf. Sci. 2011, 257, 7997-8002. [CrossRef]

53. Mohammadi, T.; Kazemimoghadam, M.; Saadabadi, M. Modeling of membrane fouling and flux decline in reverse osmosis during separation of oil in water emulsions. Desalination 2003, 157, 369-375. [CrossRef]

54. Mondal, S.; Wickramasinghe, S.R. Produced water treatment by nanofiltration and reverse osmosis membranes. J. Membr. Sci. 2008, 322, 162-170. [CrossRef]

55. Hoffmann, M.R.; Martin, S.T.; Choi, W.; Bahnemann, D.W. Environmental Applications of Semiconductor Photocatalysis. Chem. Rev. 1995, 95, 69-96. [CrossRef]

56. Peyravi, M.; Jahanshahi, M.; Mirmousaei, S.M.; Lau, W.-J. Dynamically Coated Photocatalytic Zeolite-TiO 2 Membrane for Oil-in-Water Emulsion Separation. Arab. J. Sci. Eng. 2020, 1-9. [CrossRef]

57. Kovács, I.; Veréb, G.; Kertész, S.; Beszédes, S.; Hodúr, C.; László, Z. Investigation of surface and filtration properties of TiO 2 coated ultrafiltration polyacrylonitrile membranes. Water Sci. Technol. 2018, 77, 931-938. [CrossRef]

58. Xie, A.; Cui, J.; Yang, J.; Cfhen, Y.; Dai, J.; Lang, J.; Li, C.; Yan, Y. Photo-Fenton self-cleaning membranes with robust flux recovery for an efficient oil/water emulsion separation. J. Mater. Chem. A 2019, 7, 8491-8502. [CrossRef] 